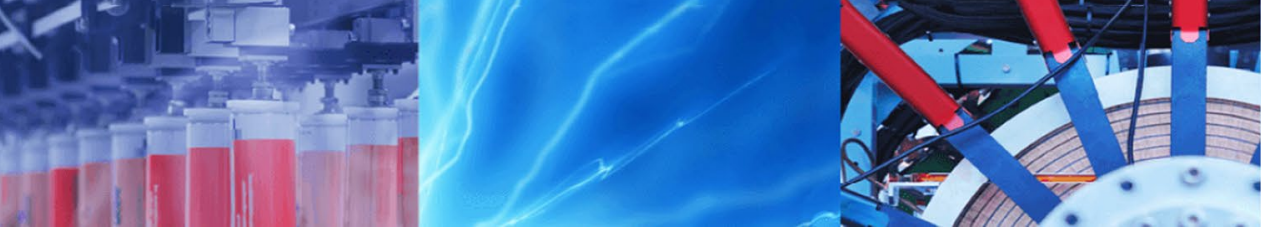

Research Article

\title{
Monitoring and modelling water quality of Loktak Lake catchment
}

\author{
Eliza Khwairakpam ${ }^{1} \cdot$ Rakesh Khosa $^{1} \cdot$ Ashvani Gosain ${ }^{1} \cdot$ Arvind Nema $^{1}$
}

(c) Springer Nature Switzerland AG 2019

\begin{abstract}
Loktak Lake is an internationally important, Ramsar designated, fresh water wetland system in the state of Manipur, India. The lake has also been listed under Montreux Record on account of the ecological modifications that the lake system has witnessed over time. Discharges from nine rivers namely Khuga, Thongjaorok, Awang Khujairok, Nambol, Nambul, Imphal, Kongba, Iril, and Thoubal have a great impact on the habitats and the overall ecological status of the lake. Monitoring of water quality at the catchment scale can be considered as an essential step towards the eventual goal to design effective conservation and management practices for the entire Loktak Lake ecosystem. This article presents the status of nine rivers draining into the Loktak Lake and correlation with land use patterns which can be used as support for making sound decisions regarding the management of the lake ecosystems. Flows were modelled using a combination of soil and water assessment tool (SWAT) and MIKE SHE, abbreviated as hybrid SHE-SWAT. Water quality models were established using MIKE 11 ECO Lab. Water quality parameters such as biological oxygen demand, dissolved oxygen and water temperature were simulated. Water quality models were calibrated using available measured water quality data procured from State Pollution Control Board and validated using observed water quality collected during the field study.
\end{abstract}

Keywords Loktak Lake · MIKE 11 ECO Lab·Water quality · Land use

\section{Introduction}

Watershed management to improve the habitat of freshwater aquatic life forms is increasingly recognized as a necessary step towards sustainability [1]. Water quality can be assessed by various parameters such as biochemical oxygen demand (BOD), dissolved oxygen (DO), temperature, etc. [2]. DO is a significant parameter for determining water quality and a key point affecting aquatic habitats [3-6]. High levels of BOD can lead to severe oxygen depletion and affect aquatic habitat $[7,8]$. Water temperature also plays an important role in reproduction and metabolic rates of aquatic life forms $[9,10]$.

Water quality study can be done using field sampling followed by laboratory analysis. However, this method has some disadvantages such as time taking, expensive and mostly confined to few point locations, thus limiting to planning and management. Water quality information in watershed level or a river system can be of paramount use to environmental policies maker. It can help them in targeting area which needs to be emphasized, saving time and resources. It can also help them in stratifying the river into various sections with different water quality which can be treated with different management practices. With advancing computational ability and increasing understanding of the hydrological system, many computer models have been evolved and still evolving for modelling catchment water quality. These models vary from simplified conceptual to empirical and to physically based models [11]. Data availability and objective of the study greatly influence the type of model to be employed for the study of water quality [12]. The semi-distributed soil and water analysis tool (SWAT) [13] has been used extensively for hydrologic modelling and water resources management. Arnold et al. [14] simulated daily water balance in upper Mississipi River basin using this model. Narsimlu et al. [15]

Eliza Khwairakpam, kh.eliza1@gmail.com | 'Department of Civil Engineering, Indian Institute of Technology Delhi, New Delhi, India.

SN Applied Sciences (2019) 1:491 | https://doi.org/10.1007/s42452-019-0517-1

Received: 30 December 2018 / Accepted: 22 April 2019 / Published online: 26 April 2019 
simulated stream flow for upper Sind River basin, India using this model. Saha et al. [16] also modelled stream flow for Yass River catchment in south-eastern Australia using this model [17]. Another widely used model for studying hydrological processes is the fully distributed Europeen Hydrological System (MIKE SHE) [18]. The literature has reported various applications of MIKE SHE, such as investigating the hydrological responses to land-use/landcover changes and climate, irrigation planning, forest fire impact assessment and forestry management, sustainable groundwater management, and hydrological manipulations of grass wetland [19-21]. ECO Lab module of MIKE 11 hydrodynamic model is used for studying water quality $[12,22]$. Butts et al. [23] simulated flows and temperatures in the Lower Wood River Valley, Idaho, US using MIKE ECO Lab. Loinaz et al. [1] employed MIKE ECO Lab for modelling streams temperature in Wood river valley and Silver Creek basin. Results from models can be used to support decision and policy making, e.g., Popescu et al. [24] and Forio et al. [25].

Loktak Lake is a RAMSAR designated, fresh water wetland system situated in the state of Manipur, India. The characteristic feature of this lake is the presence of floating islands covered with vegetation, locally known as "Phumdis" $[26,27]$. A contiguous $40 \mathrm{~km}^{2}$ area of Phumdis, on the southern part of the lake is protected as Keibul Lamjao National Park (KLNP) for the conservation of a small and isolated population of Manipur's brow-antlered deer popularly known as Sangai (Rucervus eldii). KNLP is the only floating wildlife sanctuary in the world and the only natural home to the endemic and endangered Sangai deer [28-31]. The lake is considered to be the lifeline of Manipur due to its importance in the socio-economic and cultural life of the people [32]. The lake sustains rich biological diversity with 428 species of animals and 132 plants species $[33,34]$. This lake supports hydro-power generation, provide fisheries as the livelihood to about 8700 fishermen, provides water for irrigation to about 32,400 ha agricultural area $[35,36]$. The annual benefits from Loktak Lake are about Rs 600 million, amounting to nearly $2 \%$ of the state's gross domestic product [37]. Loktak Lake catchment covers about $22 \%$ of the total Manipur state area. Manipur is a rural area $(93 \%)$ in which occupation is dominated by agriculture [38, 39].

Despite the importance of the lake, research done on water quality of the lake and its catchment are very limited. Deteriorating water quality in its catchment along with reduced fish species can be considered as emerging concerns in Loktak Lake. Some fish species which have been disappeared from the lake and its catchment include Puntius saranacaudi marginatus, Bagarius bagarius, Rotia berdmorei, Labeo boga, Labeo pangusia, Lepidocephalus berdmorei, Lepidocephalus thermalis, Mystus aor, Mystus. tengara Puntius burmanicus, Puntius hexastichus and Tor tor [40-45]. Laishram and Dey, [46] analyzed water quality of Loktak Lake and found that biological oxygen demand (BOD) was higher than the World Health Organization (WHO) guideline. Tuboi et al. [47] found that the Loktak Lake to be hypertrophic, leading to decrease in water quality causing adverse impacts on the ecosystem. State Pollution Control Board (SPCB), Government of Manipur monitor water quality of Loktak catchment three times annually.

Loktak Lake has been listed under Montreux Record on account of the ecological modifications that the lake system has witnessed over time [48]. Discharges from nine rivers namely Khuga, Thongjaorok, Awang Khujairok, Nambol, Nambul, Imphal, Kongba, Iril and Thoubal have a great impact on the habitats and the overall ecological status of the lake. Figure 1 shows the location of nine rivers draining into the Loktak Lake. Monitoring of water quality at the catchment scale can be considered as an essential step towards the eventual goal to design effective conservation and management practices for the entire Loktak Lake ecosystem.

Acknowledging the importance of the Loktak Lake in terms of socio-economic and biodiversity conservation, this paper presents the study of the status of nine rivers draining into the Loktak Lake and correlation with land use patterns which can be used as support for making sound decisions regarding the management of the lake ecosystem. Water quality models were established for the nine rivers using MIKE 11 ECO Lab. Water quality parameters such as dissolved oxygen (DO), biological oxygen demand (BOD) and water temperature were simulated. Water quality models were calibrated using available measured water quality data procured from SPCB and validated using observed water quality collected during a field study. Further, the obtained spatial water quality was analysed and correlated to land use pattern to gain an understanding of human induced land cover change effect to the catchment water quality, which in turn affects the Loktak Lake ecosystem.

\section{Study area}

Loktak Lake, the largest fresh water lake in Northeast region is situated in the state of Manipur, India (Fig. 1). The lake covers an area of about $287 \mathrm{~km}^{2}$ with a catchment area of approximately $5040 \mathrm{~km}^{2}[27,49,50]$. Elevation of the catchment ranges from $744 \mathrm{~m}$ above mean sea level (amsl) in the valley to $2559 \mathrm{~m}$ amsl in hilly regions. The soil of the catchment area consists of mostly clay and silt [51]. Field study indicated that top layer soil ranges from moderate to slightly acidic ( $\mathrm{pH} 4.5$ to 5.2 ). The mean annual temperature is about $24^{\circ} \mathrm{C}$ during summer (May-July) and 


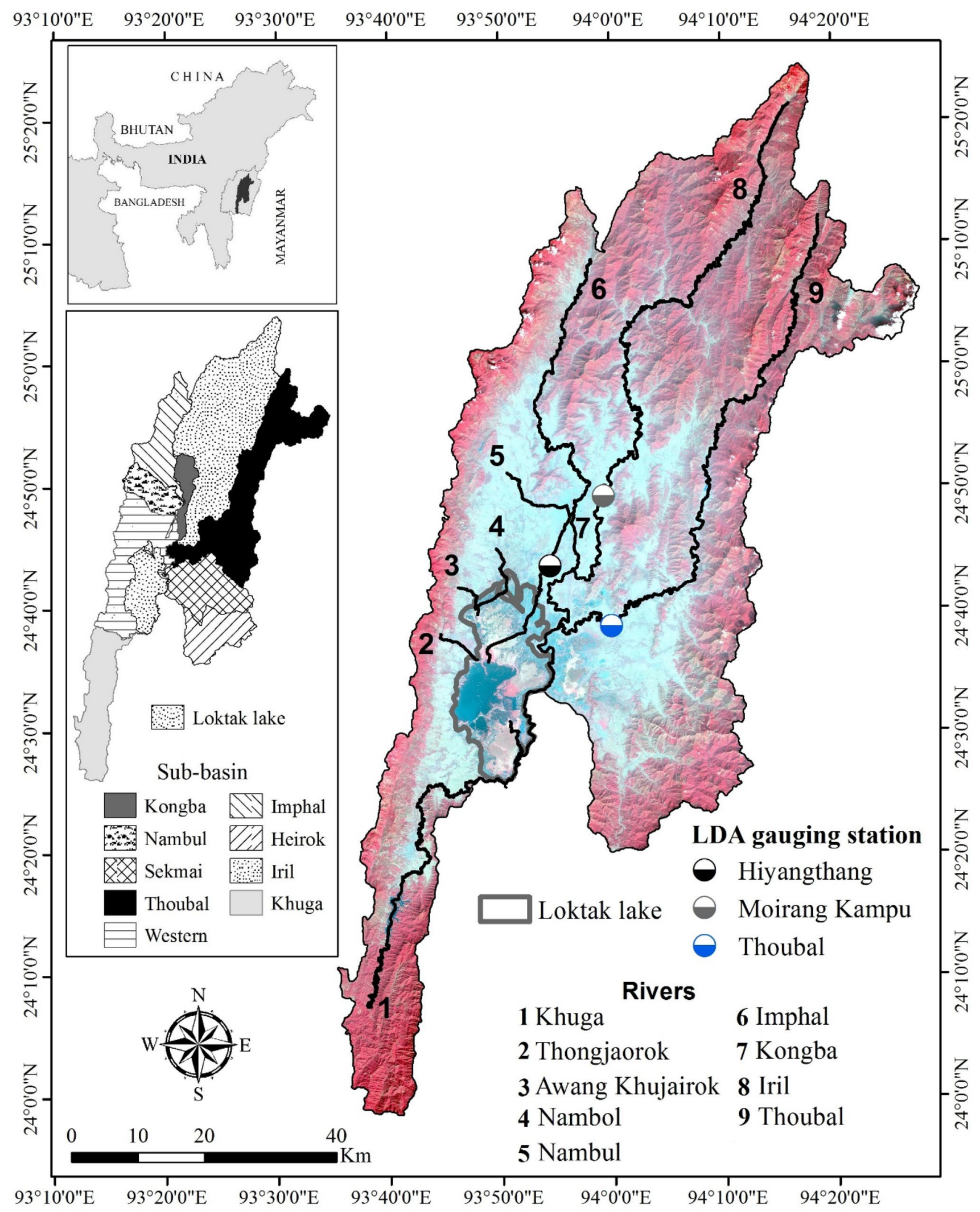

Fig. 1 Loktak Lake, its rivers, and sub-catchments in Northeast India 
$14{ }^{\circ} \mathrm{C}$ during winter (November-January) [31]. The catchment area experiences relative humidity ranging from 51 to $81 \%$, and wind speed ranging between 2 and $5 \mathrm{~km} / \mathrm{h}$ in average annually [35]. On an average, the catchment receives an annual rainfall of about $1392 \mathrm{~mm}$, within 150 rainy days in a year and pan-evaporation ranges between 19 and $130 \mathrm{~mm}[35,52]$.

Hydrologically, Loktak Lake is dependent on nine major rivers namely Khuga, Thongjaorok, Awang Khujairok, Nambol, Nambul, Imphal, Kongba, Iril, and Thoubal. The lake catchment can be divided into nine sub-catchments namely, Khuga, Western, Nambul, Imphal, Kongba, Iril, Thoubal, Heirok and Sekmai. However, Heirok and Sekmai Rivers no longer contributes due to diversion scheme [33]. Thongjaorok, Awang Khujairok and Nambol Rivers lie in Western sub-catchments as shown in Fig. 1.

The land use of Loktak catchment can be broadly divided into agricultural areas, forest, settlement, water, and phumdis as shown in Table 1. Digital land use map of the year 2003 was procured from Forest Department, Government of Manipur. Agricultural areas consist of about $1406 \mathrm{~km}^{2}$ (27\%) of the total Loktak catchment including Heirok and Sekmai sub-catchments. The dominant crop grown in the catchment area is rice. The paddy cultivation practiced in the valley area of the catchment accounts for about $65 \%$ of the overall production of the entire state [28]. The forest area can further be sub-divided into dense forest, degraded forest, and jhum. Jhum are initially forested areas which are burned down and cleared by the local people to be able to use for agricultural purposes [28]. The practice of jhum is also known as shifting cultivation. Forest area constitute the largest amount covering about $59 \%$ of the total catchment area. Of these forested areas, dense forest constitutes about $27 \%$, degraded forest (16\%) and jhum (16\%). Tropical semi-evergreen, subtropical pine and montane wet temperate forests are major types of forest found in the catchment area [53, 54]. The practice of jhum can be considered as a major factor for degradation of the dense forest. Settlement constitutes about $222 \mathrm{~km}^{2}(4 \%)$ of the total catchment area including
Heirok and Sekmai sub-catchments. The population of Manipur state is concentrated mainly in the central valley area. Water bodies constitute about $5 \%$ of the total catchment area, while phumdis constitute about 3\%. A matured phumdis is about 1 to $2 \mathrm{~m}$ thick, solid and strong enough which can support the weight of thatched houses built on it [37]. The number of recorded phum huts built by fishermen on phumdis for shelter is 733 [35]. These people who are living on phumdis practice dumping of domestic waste directly on the lake.

\section{Brief description of models}

Hybrid SHE-SWAT employed for developing a hydrological model for each sub-catchments can be found from the literature [55]. Water quality model of the nine rivers was developed by using MIKE 11 ECO Lab module. ECO Lab is a flexible numerical laboratory for ecological modelling [56]. It is a tool which can be used to customize an ecosystem model to simulate water quality, ecological conditions and so on. This is an ecological modelling module which can simulate $\mathrm{DO}, \mathrm{BOD}$, temperature and other parameters. This module has several pre-developed ECO Lab templates that are suitable for various conditions. The ECO Lab model describes the biological, chemical, ecological processes and the interactions between the state variables in addition to the physical process of sedimentation of the components. The State variables in ECO Lab can be transported based on the hydrodynamics through the advection-dispersion process. The differential equation describing the oxygen concentration is given in Eq. (1).

$$
\begin{aligned}
\frac{d(D O)}{d t}= & K_{2}\left(D O_{s a t}-D O\right)-R+P-B-K_{3} * C(B O D) \\
& -Y * K_{4} * C\left(\mathrm{NH}_{4}\right)^{n l}
\end{aligned}
$$

where $K_{2}$ is the reaeration constant; $D O$ is dissolved oxygen; $D O_{\text {sat }}$ is the oxygen saturation constant; $K_{3}$ is the
Table 1 Landuse of Loktak Lake sub-catchments

\begin{tabular}{lrrrrrrr}
\hline Land use $\left(\mathrm{km}^{2}\right)$ & \multicolumn{2}{l}{ Sub-catchments } \\
\cline { 2 - 8 } & Nambul & Kongba & Imphal & Khuga & Western & Iril & Thoubal \\
\hline Agriculture & 91.61 & 50.78 & 95.16 & 63.23 & 304.82 & 307.53 & 275.60 \\
Dense forest & 47.95 & 17.00 & 132.62 & 172.15 & 70.66 & 594.40 & 232.94 \\
Degraded forest & 15.05 & 10.86 & 58.27 & 45.46 & 43.32 & 270.15 & 316.92 \\
Jhum & 10.82 & 15.03 & 41.07 & 215.21 & 72.88 & 140.74 & 89.77 \\
Settlement & 20.82 & 25.34 & 18.68 & 6.82 & 64.61 & 19.70 & 26.16 \\
Water & 3.67 & 1.77 & 3.19 & 1.60 & 218.82 & 4.90 & 6.52 \\
Phumdis & 6.39 & 2.71 & 2.19 & 2.88 & 70.62 & 1.39 & 11.66 \\
Total & 196.31 & 123.48 & 351.17 & 507.35 & 845.72 & 1338.82 & 959.57 \\
\hline
\end{tabular}


degradation constant; $K_{4}$ is the nitrification rate; $Y$ is the oxygen consumption per nitrification unit; $n l$ is the reaction order of nitrification; $R$ is respiration; $P$ is photosynthesis; $B$ is sediment oxygen demand.

The BOD concentration is described by the following differential Eq. (2).

$\frac{d(C(B O D))}{d t}=K_{3} C(B O D)+$ resuspension - sedimentation

Resuspension occurs when the flow velocity exceeds a critical value. Resuspension is assumed to be constant in time, and at flow velocities smaller than the critical value, sedimentation will occur.

\section{Model development}

\subsection{Water quality model}

Hydrological models for each Loktak Lake sub-catchments, namely Khuga, Awang Khujairok, Nambol, Nambul, Imphal, Kongba, Iril, and Thoubal were developed using hybrid SHE-SWAT. Based on differences in hydrological response, each sub-catchments were delineated into hilly and valley regions except Kongba sub-catchment. Kongba sub-catchment, located in central part of the catchment, consist of only valley region. Hilly regions were modelled using SWAT while valley regions were modeled using MIKE SHE. Further details of hybrid SHE-SWAT models for Loktak Lake sub-catchments can be found from the literature [55]. The flowchart for the flow and water quality models development is shown in Fig. 2. Considering lack of concurrence of river discharges and water quality data, flows from each rivers were simulated for the time period January 2011 to December 2016. Surface water quality of nine major rivers was modelled using ECO Lab module of MIKE 11. The model set up includes river network, river cross sections, boundary condition, hydrodynamic parameters, advection dispersion and ECO Lab parameters. Among the three built-in integration routines of the module, EULER (Euler or Linear solution) was specified during the initial calibration stage considering lesser computing time. Later on, RKQC (Fifth order Runge-Kutta with Quality Control) was used for all nine models. Observed DO, BOD and temperature were obtained from SPCB, Government of Manipur (GoM) for years 2011 to 2016 observed three times annually. In addition, a field survey was also conducted for the two different time periods: 25 January 2016 to 31 January 2016 and 5 August 2016 to 15 August 2016. DO, BOD and temperature were collected for every $1 \mathrm{~km}$ in all the rivers. However, out of the nine rivers, upstream of Khuga, Imphal, Iril and Thoubal Rivers were not collected due to inaccessibility as a result of hilly terrain and security problem. Dissolved oxygen probe was used for measuring DO, and five-day test for biochemical oxygen demand test was used for measuring BOD. Water temperature was measured using a thermometer.

\subsection{Model calibration and validation}

Calibration and validation of hydrological models of subcatchments can be found from the literature [55]. DO, BOD and temperature for the nine rivers were simulated from MIKE 11 ECO Lab models at every $1 \mathrm{~km}$ for the time period 2011 to 2016. The nine models were calibrated during

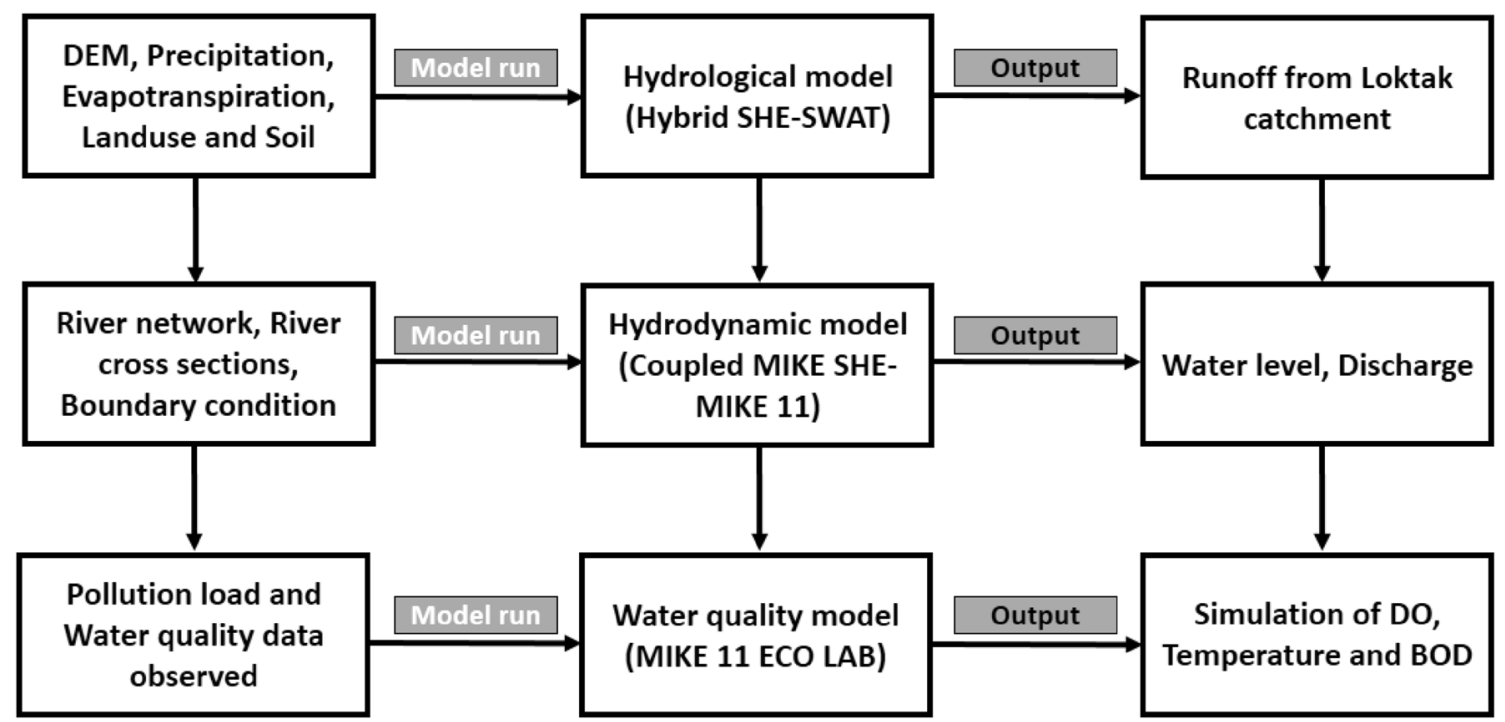

Fig. 2 Flowchart of the flow and water quality models development 
2011 to 2015 and validated for dry (25 January 2016 to 31 January 2016) and wet (5 August 2016 to 15 August 2016) seasons. The final calibrated values for dispersion coefficient (D) and reaeration constant (K) for the nine rivers are shown in Table 2. The values for $D$ and $K$ ranges from 3 to $7 \mathrm{~m}^{2} \mathrm{~s}^{-1}$ and 0.3 to 0.8 respectively. Each model was validated using observed data collected during the field survey.

Figures 3 and 4 show observed versus simulated DO and BOD for nine rivers during two different time periods: 25 January 2016 to 31 January 2016 and 5 August 2016 to 15 August 2016 respectively. The comparison of observed and simulated temperature for nine rivers during two time periods are shown in Figs. 5 and 6. Table 3 also shows the statistical evaluation of the nine rivers during the validation period: dry season (25 January 2016 to 31 January 2016) and wet season (5 August 2016 to 15 August 2016). For the dry season, the Pearson coefficient (R) of DO for the nine models ranges from 0.071 to 0.985 with median 0.845 . Higher R represents the higher accuracy of models which may be due to less modelling errors and the ability of the model to capture the processes affecting water quality parameters. In this case, higher $\mathrm{R}$ is shown by Khuga, Thongjaorok, Nambol, Nambul, Imphal, Kongba, Iril and Thoubal models. However, Awang Khujairok shows low $\mathrm{R}$ which may be due to a different time interval during water quality data collection for calibration and validation period. The models also show less modelling errors with root mean square error (RMSE) ranging from 0.107 to 1.82 . mean absolute error (MAE) also varies from 0.082 to 0.954 . For wet season also, $R$ varies from to 0.228 to 0.979 with median 0.808. In addition, RMSE varies from 0.137 to 2.575 .

Similarly, evaluation of BOD for both dry and wet seasons are shown in Table 3. For the dry season, $R$ varies from 0.785 to 0.967 with median 0.91 . Higher $R$ is shown by Khuga, Nambol, Nambul, Imphal, Iril and Thoubal

Table 2 Calibrated parameter values of MIKE 11 ECO Lab models

\begin{tabular}{lll}
\hline River & $A D^{*}\left(\mathrm{D}, \mathrm{m}^{2} \mathrm{~s}^{-1}\right)$ & $\begin{array}{l}\mathrm{WQ}^{* *} \\
\text { (reaera- } \\
\text { tion, } \mathrm{K})\end{array}$ \\
\hline Khuga & 6 & 0.5 \\
Thongjaorok & 7 & 0.7 \\
Awang Khujairok & 6 & 0.7 \\
Nambol & 6 & 0.6 \\
Nambul & 3 & 0.3 \\
Imphal & 5 & 0.4 \\
Kongba & 4 & 0.3 \\
Iril & 7 & 0.8 \\
Thoubal & 7 & 0.8 \\
\hline
\end{tabular}

*Advection dispersion; ** water quality

SN Applied Sciences

SPRINGER NATURE journal models indicating higher accuracy of models. However, Thongjaorok, Awang Khujairok and Kongba models show lesser $\mathrm{R}$ probably due to a different time interval during data collection for calibration and validation period. RMSE and MAE also vary from 0.142 to 1.833 and 0.12 to 0.926 respectively. During the wet season, the nine models show $\mathrm{R}$ ranging from 0.21 to 0.979 with median 0.947 . The nine models show low RMSE ranging from 0.104 to 2.689. MAE also varies from 0.10 to 1.39 .

Evaluation of water temperature for the validation period is also shown in Table 3. For the dry season, $\mathrm{R}$ varies from 0.192 to 0.945 with median 0.839. RMSE and MAE vary from 0.059 to 1.623 and 0.043 to 0.735 respectively. For the wet season, $R$ varies from 0.473 to 0.907 with median 0.786 . In terms of errors, RMSE and MAE vary from 0.148 to 3.786 to 0.1 to 1.83 respectively.

\section{Results}

Figures 7,8 and 9 show simulated DO, BOD and temperature for winter, summer and rainy seasons 2016 respectively. For the nine rivers, DO and BOD are inversely proportional in general. During the winter season, downstream of Nambul River shows DO of less than $0.5 \mathrm{mg} / \mathrm{L}$ as shown in Fig. 7. DO of upstream of Nambul and Kongba Rivers ranges from 0.5 to $1 \mathrm{mg} / \mathrm{L}$. Conclusively among all nine rivers, Iril, Thoubal and upstream of Khuga show DO of above $4 \mathrm{mg} / \mathrm{L}$. In terms of temperature, Nambul and Kongba Rivers show comparatively higher temperature $\left(21-26^{\circ} \mathrm{C}\right)$ as compared to remaining seven rivers. Nambul, Kongba and downstream of Imphal Rivers show higher BOD greater than $10 \mathrm{mg} / \mathrm{L}$.

Figure 8 shows simulated $\mathrm{DO}$, temperature and BOD for Khuga, Thongjaorok, Awang Khujairok, Nambol, Nambul, Imphal, Kongba, Iril and Thoubal Rivers during the summer season. This figure shows spatial water quality in Loktak Lake catchment. Khuga, Thongjaorok, Awang Khujairok, Nambol, Nambul, Imphal, Kongba Rivers show DO of less than $4 \mathrm{mg} / \mathrm{L}$. Nambul and Kongba Rivers show high temperature ranging from 31 to $33^{\circ} \mathrm{C}$. In this season, BOD is greater than $10 \mathrm{mg} / \mathrm{L}$ in all nine rivers except upstream of Khuga, Iril and Thoubal. As the monsoon period starts from the month of June and continues till September, DO is comparatively higher during the wet season as compared to dry season (Fig. 9). In the same way, BOD is comparatively lower as compared to the dry season. However, DO is still showing less than $4 \mathrm{mg} / \mathrm{L}$ for Khuga (downstream), Thongjaorok, Awang Khujairok, Nambol, Nambul, Imphal and Kongba Rivers. In addition, BOD is also higher than $10 \mathrm{mg} / \mathrm{L}$ in Nambul, Kongba and Imphal (downstream) 

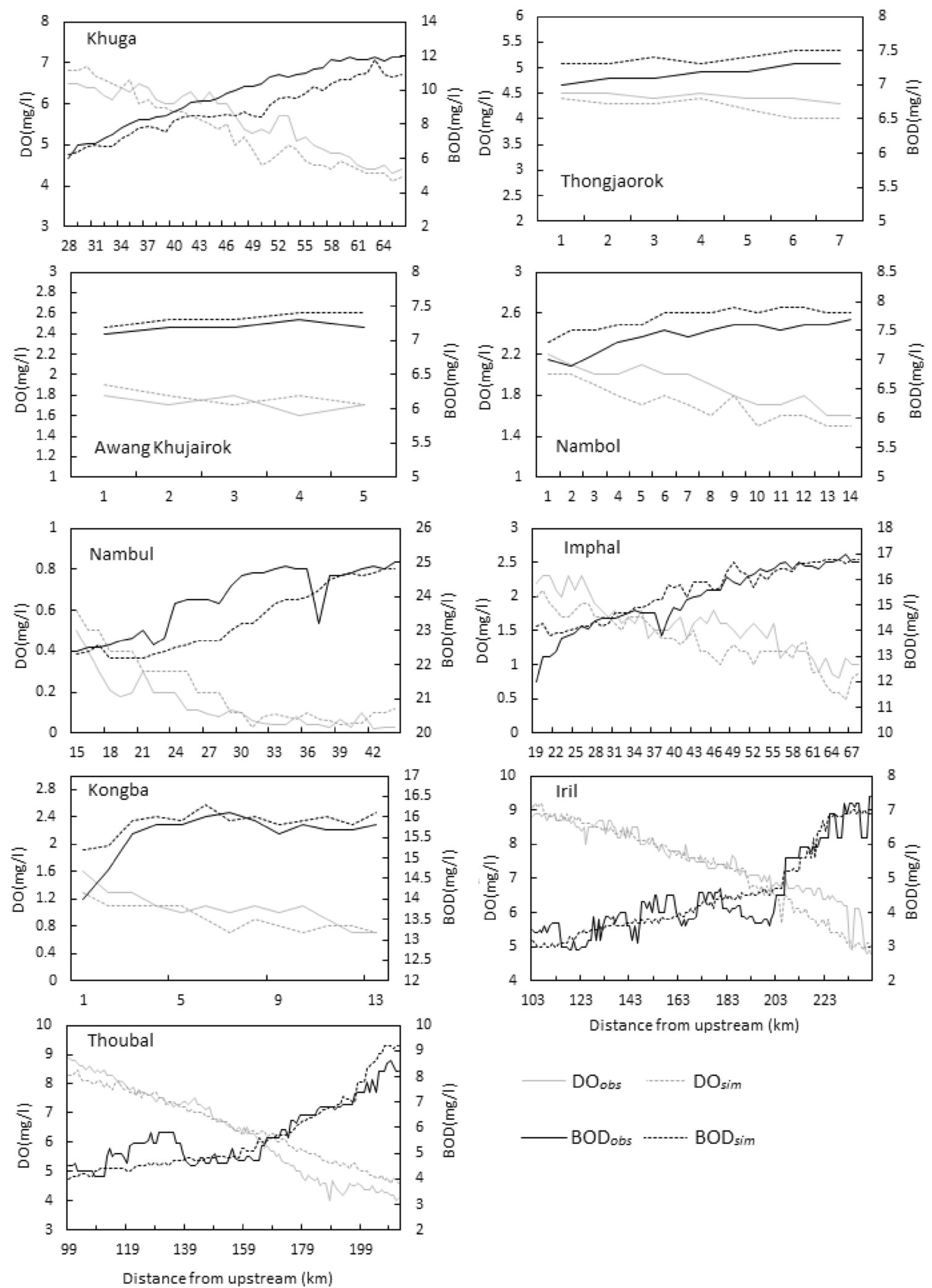

Fig. 3 Observed versus simulated DO and BOD for nine rivers draining into the Loktak Lake during 25 January 2016 to 31 January 2016 

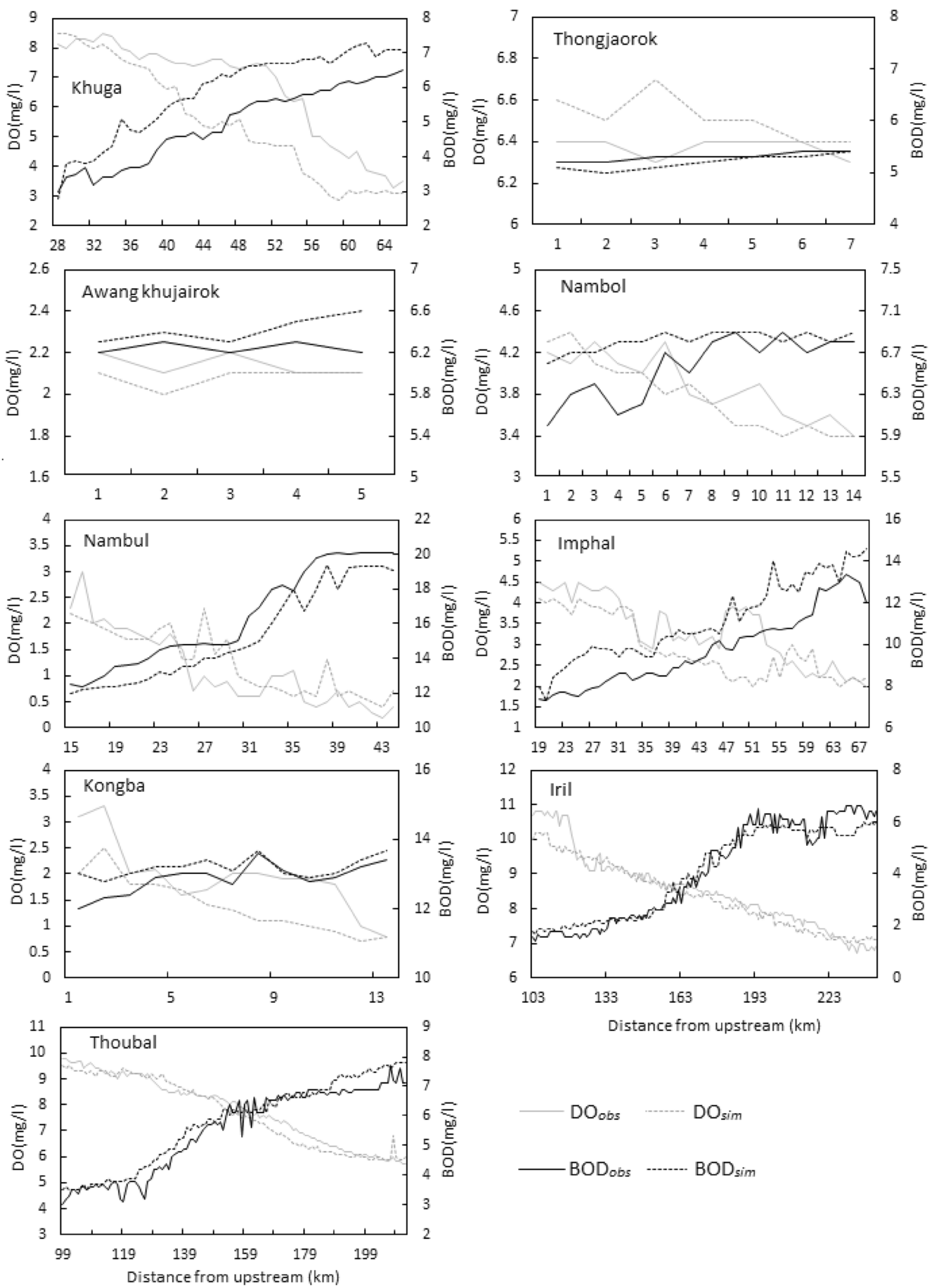

$\mathrm{DO}_{o b s} \quad \cdots \mathrm{DO}_{\text {sim }}$

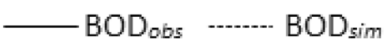

Fig. 4 Observed versus simulated DO and BOD for nine rivers draining into the Loktak Lake during 5 August 2016 to 15 August 2016 

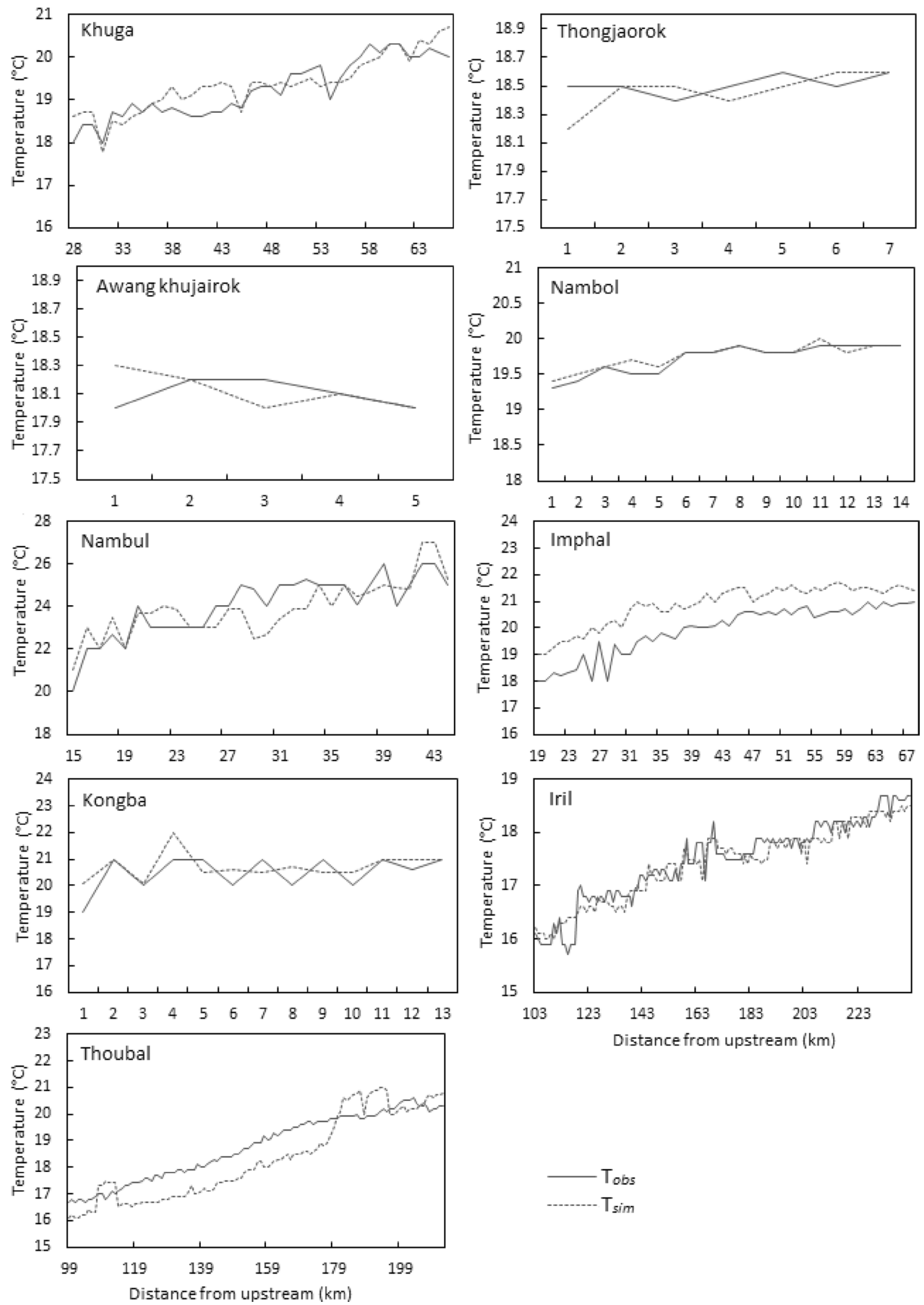

Fig. 5 Observed versus simulated temperature for nine rivers draining into the Loktak Lake 25 January 2016 to 31 January 2016 

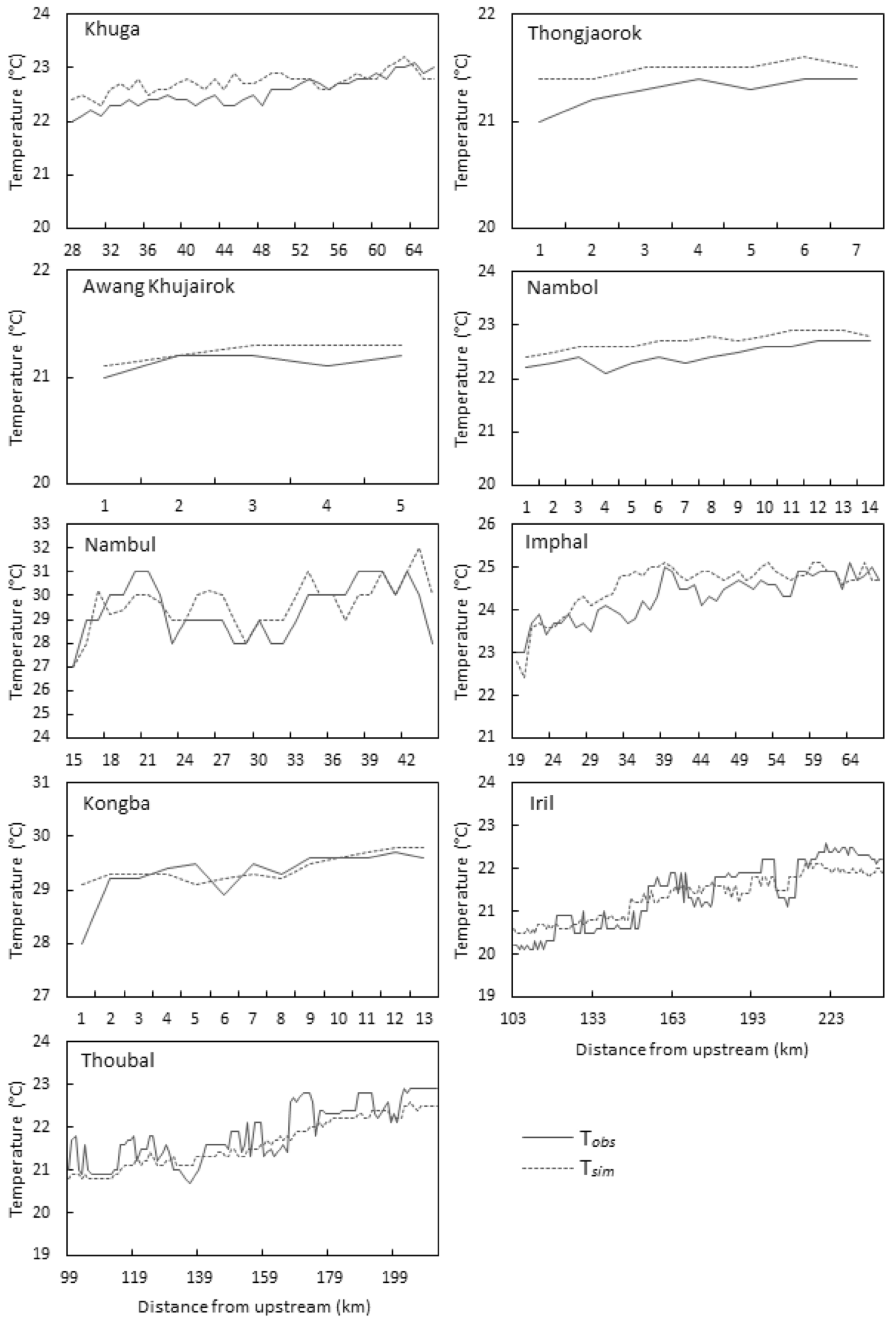

Fig. 6 Observed versus simulated temperature for nine rivers draining into the Loktak Lake during 5 August 2016 to 15 August 2016 
Table 3 Statistical analysis of water quality models for nine rivers during the validation period

\begin{tabular}{|c|c|c|c|c|c|c|c|c|c|c|c|}
\hline \multirow[t]{2}{*}{ Sl. no. } & \multirow[t]{2}{*}{ Rivers } & \multirow[t]{2}{*}{ Season } & \multicolumn{3}{|c|}{$\mathrm{DO}(\mathrm{mg} / \mathrm{L})$} & \multicolumn{3}{|c|}{ Temperature $\left({ }^{\circ} \mathrm{C}\right)$} & \multicolumn{3}{|c|}{$\mathrm{BOD}(\mathrm{mg} / \mathrm{L})$} \\
\hline & & & RMSE & MAE & $\mathrm{R}$ & RMSE & MAE & $\mathrm{R}$ & RMSE & MAE & $\mathrm{R}$ \\
\hline \multirow[t]{2}{*}{1} & Khuga & Dry & 0.792 & 0.385 & 0.911 & 0.628 & 0.290 & 0.870 & 1.833 & 0.926 & 0.967 \\
\hline & & Wet & 2.575 & 1.210 & 0.885 & 0.474 & 0.223 & 0.738 & 1.772 & 0.943 & 0.956 \\
\hline \multirow[t]{2}{*}{2} & Thongjaorok & Dry & 0.402 & 0.200 & 0.832 & 0.241 & 0.043 & 0.225 & 0.396 & 0.214 & 0.785 \\
\hline & & Wet & 0.328 & 0.143 & 0.228 & 0.391 & 0.200 & 0.801 & 0.222 & 0.100 & 0.866 \\
\hline \multirow[t]{2}{*}{3} & Awang Khujairok & Dry & 0.210 & 0.100 & 0.071 & 0.286 & 0.100 & 0.192 & 0.224 & 0.120 & 0.845 \\
\hline & & Wet & 0.137 & 0.060 & 0.409 & 0.210 & 0.100 & 0.473 & 0.380 & 0.180 & 0.210 \\
\hline \multirow[t]{2}{*}{4} & Nambol & Dry & 0.295 & 0.178 & 0.843 & 0.125 & 0.050 & 0.945 & 0.266 & 0.307 & 0.883 \\
\hline & & Wet & 0.303 & 0.171 & 0.785 & 0.225 & 0.264 & 0.833 & 0.597 & 0.271 & 0.738 \\
\hline \multirow[t]{2}{*}{5} & Nambul & Dry & 0.183 & 0.082 & 0.905 & 1.623 & 0.723 & 0.773 & 1.486 & 0.673 & 0.804 \\
\hline & & Wet & 0.780 & 0.330 & 0.808 & 3.786 & 1.830 & 0.635 & 2.163 & 1.080 & 0.978 \\
\hline \multirow[t]{2}{*}{6} & Imphal & Dry & 1.820 & 0.954 & 0.845 & 0.547 & 0.234 & 0.839 & 1.008 & 0.370 & 0.915 \\
\hline & & Wet & 0.890 & 0.264 & 0.719 & 0.793 & 0.344 & 0.786 & 2.689 & 1.390 & 0.947 \\
\hline \multirow[t]{2}{*}{7} & Kongba & Dry & 0.371 & 0.177 & 0.767 & 1.011 & 0.454 & 0.568 & 0.748 & 0.308 & 0.910 \\
\hline & & Wet & 1.177 & 0.562 & 0.820 & 0.624 & 0.223 & 0.627 & 0.734 & 0.331 & 0.786 \\
\hline \multirow[t]{2}{*}{8} & Iril & Dry & 0.107 & 0.310 & 0.959 & 0.059 & 0.201 & 0.949 & 0.161 & 0.388 & 0.932 \\
\hline & & Wet & 0.244 & 0.247 & 0.965 & 0.148 & 0.334 & 0.907 & 0.104 & 0.348 & 0.979 \\
\hline \multirow[t]{2}{*}{9} & Thoubal & Dry & 0.195 & 0.402 & 0.985 & 0.254 & 0.735 & 0.922 & 0.142 & 0.428 & 0.935 \\
\hline & & Wet & 0.143 & 0.238 & 0.979 & 0.237 & 0.339 & 0.877 & 0.112 & 0.321 & 0.975 \\
\hline
\end{tabular}

$R M S E$ root mean square error, $M A E$ mean absolute error, $R$ correlation coefficient

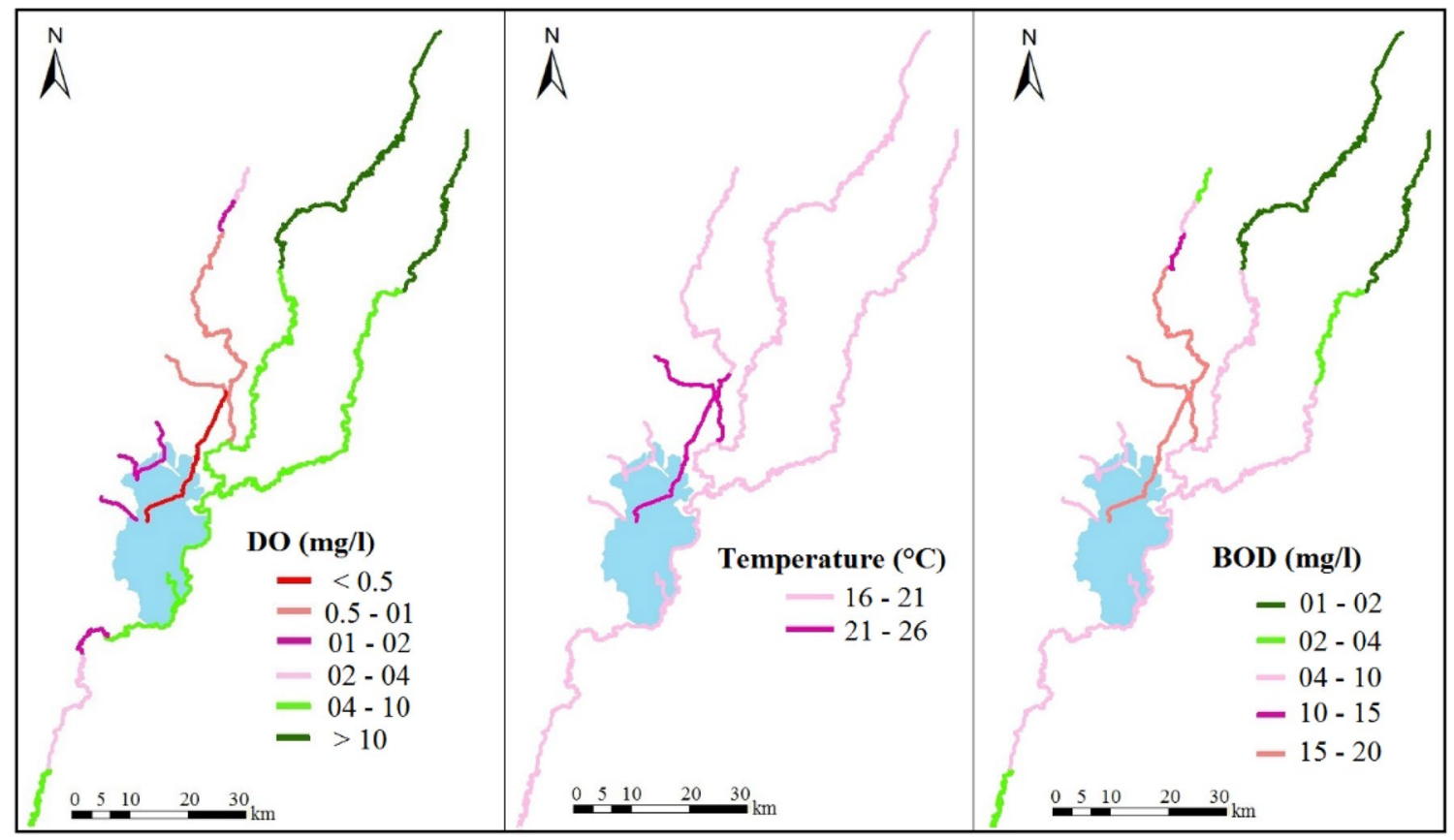

Fig. 7 Simulated DO, temperature and BOD for winter season 2016

Rivers. Water temperature for all nine rivers ranges from 21 to $31^{\circ} \mathrm{C}$.

It is evident from the Figs. 7, 8 and 9 that there are relatively seasonal and spatial changes of surface water quality in Loktak catchment. The two rivers namely Nambul and Kongba Rivers show DO of less than $4 \mathrm{mg} / \mathrm{L}$ throughout the year. BOD is also found to be higher than $10 \mathrm{mg} / \mathrm{L}$. High BOD in Nambul and Kongba indicates high pollution loads due to use of agricultural pesticides and fertilizers and dumping of domestic waste. Landuse map of Nambul 


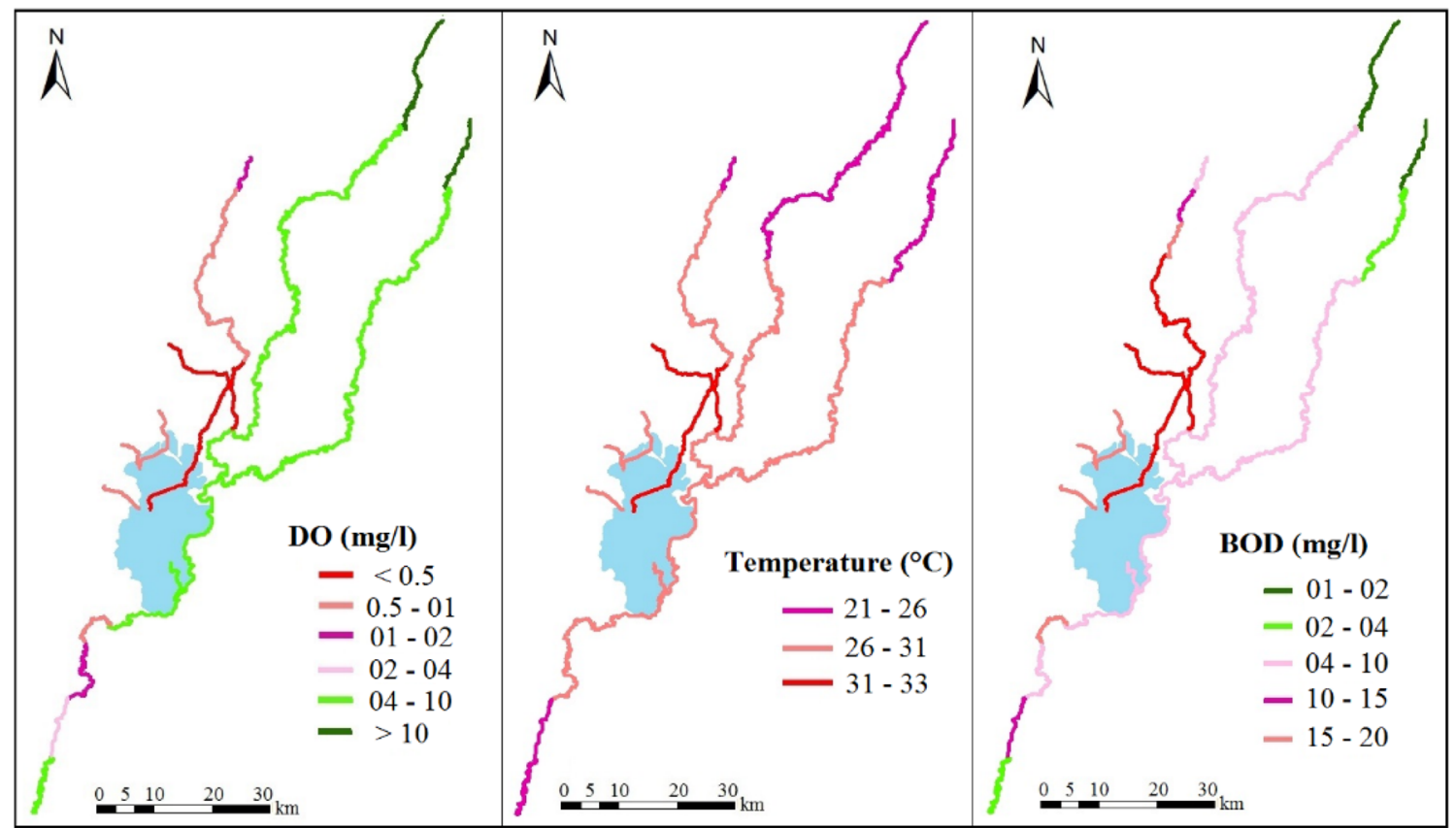

Fig. 8 Simulated DO, temperature and BOD for summer season 2016

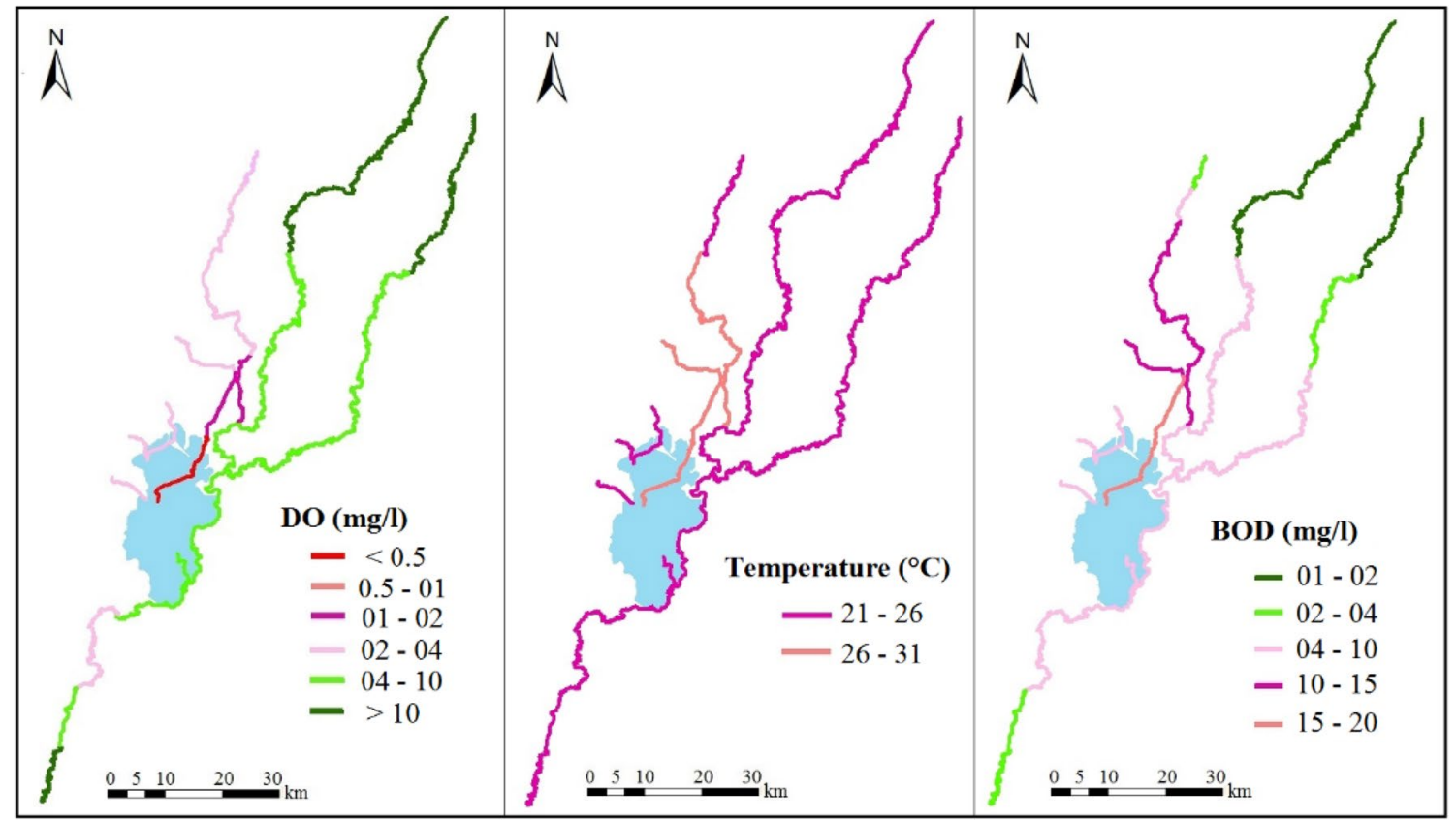

Fig. 9 Simulated DO, temperature and BOD for rainy season 2016

and Kongba sub-catchments shows high coverage of agricultural area as shown in Table 1. The agricultural area covers about $91 \mathrm{~km}^{2}$, constituting about $47 \%$ of the total Nambul sub-catchment. In Kongba sub-catchment also, agricultural area covers about $50 \mathrm{~km}^{2}(41 \%)$. The dominant crop of agriculture in this area is paddy cultivation.
Nitrogen and Phosphorus fertilizers are commonly used in paddy cultivation. This, in turn, leads to an increase of nutrients in water contributing to eutrophication of rivers. In addition, Nambul and Kongba Rivers flow through the residential areas such as Imphal, Sagolband, Singjamei which have a major contribution to pollution loads 
due to dumping of domestic waste. Settlement areas in Nambul and Kongba sub-catchments cover about $20 \mathrm{~km}^{2}$ (11\%) and $25 \mathrm{~km}^{2}$ (21\%) respectively. DO of Imphal River is found to be lesser than $4 \mathrm{mg} / \mathrm{L}$, while BOD is found to be higher than $10 \mathrm{mg} / \mathrm{L}$. Landuse of Imphal sub-catchment shows forest area covering about $132 \mathrm{~km}^{2}(38 \%)$, degraded forest of about $58 \mathrm{~km}^{2}(17 \%)$, settlement area of about $18 \mathrm{~km}^{2}(5 \%)$ and Jhum cultivation of $41 \mathrm{~km}^{2}$ (12\%). Downstream of Khuga is found to show DO of less than $4 \mathrm{mg} / \mathrm{L}$ in contrast to higher occupancy by dense forest (34\%). This is probably due to high contribution of jhum cultivation area in Khuga sub-catchment, covering about $215 \mathrm{~km}^{2}$ (42\%). Jhum cultivation leads to soil erosion of catchment area with slightly acidic soil $(\mathrm{pH} 4.5$ to 5.2). Nambol, Awang Khujairok and Thongjaorok Rivers located in western sub-catchment are also found to have DO lesser than 4 mg/L. Nambol, Awang Khujairok and Thongjaorok Rivers located in western sub-catchment are also found to have DO lesser than $4 \mathrm{mg} / \mathrm{L}$. Western sub-catchment consist of mostly agriculture $(36 \%)$ and water bodies (26\%). Among all the nine rivers, Thoubal and Iril Rivers are found to have better water quality in terms of DO and BOD. These two rivers show DO of higher than $4 \mathrm{mg} / \mathrm{L}$ throughout the year. BOD is also lesser than $10 \mathrm{mg} / \mathrm{L}$ throughout the year. Landuse of Thoubal subcatchment shows high contribution of dense forest (24\%) degraded forest (33\%) and agriculture (29\%). Landuse of Iril sub-catchment consist of mainly dense forest (44\%), degraded forest (20\%) and agriculture (23\%). Further, in order to understand the change of landuse in the Loktak catchment area, landuse map for two different time period (2001 and 2012) was downloaded from Moderate Resolution Imaging Spectroradiometer (MODIS). Landuse maps show that there is increase of cropland area from about $631 \mathrm{~km}^{2}$ (2001) to $637 \mathrm{~km}^{2}$ (2012) while Deciduous Broadleaf forest has decreased from about $13 \mathrm{~km}^{2}$ (2001) to $3 \mathrm{~km}^{2}$ (2012). Thus, there is an influence of land use to the water quality of Loktak Lake catchment. A proper waste management practices is needed in Khuga downstream (30 to $66 \mathrm{~km}$ ), Thongjaorok, Awang Khujairok, Nambol, Nambul, Imphal and Kongba sub-catchments so that BOD and DO can be brought to an acceptable level where aquatic life can flourish. There is a need to improve the water quality of rivers mainly Nambul and Kongba for conserving the Loktak Lake ecosystem.

\section{Conclusions}

The study was conducted on Loktak Lake catchment located in Northeast India to assess the water quality of nine rivers draining into the Loktak Lake and to correlate to its land use to support decision and policy making.
Flows were simulated using hybrid SHE-SWAT model. Water quality models were developed for nine rivers namely, Khuga, Thongjaorok, Awang Khujairok, Nambol, Nambul, Imphal, Kongba, Iril and Thoubal draining into the Loktak Lake using MIKE 11 ECO Lab during January 2011 to December 2016. The models were calibrated using observed water quality obtained from SPCB and validated using observed water quality data obtained using field survey. The statistical evaluation of the used models indicated less modelling errors and applied successfully. Water quality parameters such as DO, BOD and water temperature were simulated. Spatial distribution of simulated DO, BOD and temperature were analysed and correlated with landuse patterns of the catchment. The analysis found that Nambul and Kongba Rivers showed DO of less than $4 \mathrm{mg} / \mathrm{L}$ and BOD of greater than $10 \mathrm{mg} / \mathrm{L}$ throughout the year. Low DO and High BOD in Nambul and Kongba Rivers can be due to high pollution loads contributed by use of agricultural pesticides and fertilizers and dumping of domestic waste. In Khuga catchment, there is less settlement (1\%) while dense forest covers about 34\%. However, downstream of Khuga River shows DO of less than $4 \mathrm{mg} / \mathrm{L}$ mostly due to high coverage of jhum cultivation (42\%). Jhum cultivation leads to soil erosion of catchment area with slightly acidic soil $(\mathrm{pH} 4.5$ to 5.2). Among all the nine rivers, Thoubal and Iril Rivers are found to have higher $\mathrm{DO}$ (higher than $4 \mathrm{mg} / \mathrm{L}$ ) and lesser BOD (higher than $10 \mathrm{mg} / \mathrm{L}$ ) throughout the year. This may be due to high coverage by forest in Thoubal and Iril sub-catchments. Thus, it can be concluded that spatial distribution of water quality in Loktak Lake catchment has high influence by land use patterns. There is need of waste management practices in Khuga downstream (30 to $66 \mathrm{~km}$ ), Thongjaorok, Awang Khujairok, Nambol, Nambul, Imphal and Kongba sub-catchments so that BOD and DO can be brought to an acceptable level. There is a need of proper waste management practices in which water quality of rivers mainly Nambul and Kongba need to be focused. The present analysis can be of great importance in making a sound decision and policy-making for the entire Loktak ecosystem.

Acknowledgement We would like to thank State Pollution Control board, Government of Manipur (GoM); State Forest Department, GoM and Loktak Development Authority for sharing observed data and extending support. The research was financed by University Grant Commission, Government of India and India Institute of Technology Delhi.

\section{Compliance with ethical standards}

Conflict of interest There is no conflict of interest in this study. 


\section{References}

1. Loinaz MC, Davidsen HK, Butts M, Bauer-Gottwein P (2013) Integrated flow and temperature modeling at the catchment scale. J Hydrol 495:238-251

2. Bhateria R, Jain D (2016) Water quality assessment of lake water: a review. Sustain Water Resour Manag 2(2):161-173

3. Even S, Mouchel JM, Servais P, Flipo N, Poulin M, Blanc S, Chabanel M, Paffoni C (2007) Modelling the impacts of Combined Sewer Overflows on the river Seine water quality. Sci Total Environ 375(1-3):140-151

4. Abbaspour KC et al (2012) Modelling hydrology and water quality in the pre-alpine/alpine Thur watershed using SWAT. Environ Monit Assess 40(1):17-24

5. Ay M, Özgür K (2017) Estimation of dissolved oxygen by using neural networks and neuro fuzzy computing techniques. KSCE J Civ Eng 21(5):1631-1639

6. Yin Z, Yu N, Liang B, Zeng J, Xie S (2016) Experimental study of dissolved oxygen transport by regular waves through a perforated breakwater. J Ocean Univ China 15(1):78-82

7. Kramer DL (1987) Dissolved oxygen and fish behavior. Environ Biol Fishes 18(2):81-92

8. Penn M, Pauer (2003) Environmental and ecological chemistry 2. Encyclopedia of life support systems. United Nations Educational, Scientific and Cultural Organization

9. Allan JD, Castillo MM (2007) Stream ecology: structure and function of running waters, 2nd edn. Springer, Dordrecht

10. Roth TR, Westhoff MC, Huwald H, Huff JA, Rubin JF, Barrenetxea G, Vetterli M, Parriaux A, Selker JS, Parlange MB (2010) Stream temperature response to three riparian vegetation scenarios by use of a distributed temperature validated model. Environ Sci Technol 44(6):2072-2078

11. Willems $P$ (2009) A time series tool to support the multi-criteria performance evaluation of rainfall-runoff models. Environ Model Softw 24(3):311-321

12. Chibole OK (2013) Modeling River Sosiani's water quality to assess human impact on water resources at the catchment scale. Ecohydrol Hydrobiol 13(4):241-245

13. Arnold JG, Srinivasan R, Muttiah RS, Williams JR (1998) Large area hydrologic modeling and assessment part I: model development. JAWRA J Am Water Resour Assoc 34(1):73-89

14. Arnold JG, Muttiah RS, Srinivasan R, Allen PM (2000) Regional estimation of base flow and groundwater recharge in the Upper Mississippi river basin. J Hydrol 227(1):21-40

15. Narsimlu B, Gosain AK, Chahar BR (2013) Assessment of future climate change impacts on water resources of Upper Sind River Basin, India using SWAT model. Water Resour Manag 27(10):3647-3662

16. Saha PP, Zeleke K, Hafeez M (2014) Streamflow modeling in a fluctuant climate using SWAT: Yass River catchment in south eastern Australia. Environ Earth Sci 71(12):5241-5254

17. Saha PP, Zeleke K, Hafeez M (2014) Streamflow modeling in a fluctuant climate using SWAT: Yass River catchment in south eastern Australia. Environ Earth Sci 71(12):5241-5254

18. Abbott MB, Bathurst JC, Cunge JA, O'Connell PE, Rasmussen J (1986) An introduction to the European Hydrological SystemSysteme Hyrdrologique European, 'SHE', 2: structure of a physically-based, distributed modelling system. J Hydrol 87:61-77

19. Demetriou C, Punthakey JF (1998) Evaluating sustainable groundwater management options using the MIKE SHE integrated hydrogeological modelling package. Environ Model Softw 14(2-3):129-140

20. Jayatilaka CJ, Storm B, Mudgway LB (1998) Simulation of water flow on irrigation bay scale with MIKE-SHE. J Hydrol 208(1-2/2):108-130
21. Rahim BEEA, Yusoff I, Jafri AM, Othman Z, Abdul Ghani A (2012) Application of MIKE SHE modelling system to set up a detailed water balance computation. Water Environ J 26(4):490-503

22. Girbaciu A, Girbaciu C, Rosu S (2016) Water quality modeling of Bega River using mike 11. Mater Plast 53(3):533-536

23. Butts M, Loinaz M, Gottwein PB, Unnasch R, Gross D (2012) Mike She-Ecolab-an integrated catchment-scale eco-hydrological modelling tool. In: XIX international conference on water recourses CMWR 2012 University of Illinois at UrbanaChampaign, June 17-22, 2012

24. Popescu I, Cioaca E, Pan Q, Jonoski A, Hanganu J (2015) Use of hydrodynamic models for the management of the Danube Delta wetlands: the case study of Sontea-Fortuna ecosystem. Environ Sci Policy 46:48-56

25. Forio MAE, Mouton $A$, Lock $K$, Boets $P$, Nguyen THT, Damanik Ambarita MN, Musonge PLS, Dominguez-Granda L, Goethals PLM (2017) Fuzzy modelling to identify key drivers of ecological water quality to support decision and policy making. Environ Sci Policy 68:58-68

26. WAPCOS (1988) Identification report on development of Loktak Lake, Manipur. Water and Power Consultancy Services (India) Limited, New Delhi

27. LDA and WISA (2003) Extension proposal. Sustainable development and water resource management of Loktak Lake. Manipur: Loktak Development Authority and New Delhi: Wetlands International-South Asia

28. Trisal T, Manihar (2004) The atlas of Loktak Lake. Manipur: Loktak Development Authority and New Delhi: Wetlands International-South Asia

29. Dey SC (2002) Conservation of biodiversity in the Keibul Lamjao National Park. Consultancy Report: Sustainable Development and Water Resource Management of Loktak Lake. New Delhi: Wetlands International-South Asia

30. Angom D (2005) Ecological studies of vegetation in Keibul Lamjao National Park, Manipur. Thesis (PhD), School of Sciences, Manipur University, Imphal, India

31. Yadav B, Eliza K (2017) A hybrid wavelet-support vector machine model for prediction of Lake water level fluctuations using hydro-meteorological data. Meas J Int Meas Confed 103:294-301

32. LDA and WISA (1999) October 1999, vol 1

33. Singh CR, Thompson JR, Kingston DG, French JR (2011) Modelling water-level options for ecosystem services and assessment of climate change: Loktak Lake, northeast India. Hydrol Sci J 56(8):1518-1542

34. WISA (Wetlands International-South Asia) (2005) Conservation and management of Loktak Lake and associated wetlands integrating Manipur River basin: detailed project report. New Delhi: Wetlands International-South Asia

35. LDA and WISA (2002) Loktak Phumdis management 2. Manipur: Loktak Development Authority. Wetlands International South Asia, New Delhi

36. IFCD (2016) Irrigation Projects report under Irrigation and Flood Control Department, Manipur 2015-2016. Gov. Manipur

37. LDA and WISA (2010) Caring for wetlands: an answer to climate change. LDA vol V, no. February, 2010

38. Government of India (2011) Census 2011

39. Government of Manipur (2012) Annual plan (2012-13)

40. Hora SL (1921) Fish and fisheries of Manipur with some observations on those of the Naga Hills. Rec Indian Museum 22:165-214

41. Viswas S (1978) Fishes of Manipur, M.Sc Dissertation, J.N.U

42. Bhatia B (1979) Ecological study of Loktak Lake,Final Technical Report, DST, Government of India, New Delhi

43. Singh MP (1996) Ecology of Loktak Lake with special reference to fish and fisheries of the lake. PhD thesis, Manipur University

44. FD (1996) Fishery Department, Government of Manipur 
45. G. of Manipur (2016) Fishery Department

46. Laishram J, Dey M (2014) Water quality status of Loktak Lake, Manipur, Northeast India and need for conservation measures: a study on five selected villages. Int J Sci Res Publ 4(6):1-5

47. Tuboi C, Irengbam M, Hussain SA (2017) Seasonal variations in the water quality of a tropical wetland dominated by floating meadows and its implication for conservation of Ramsar wetlands. Phys Chem Earth Parts A/B/C 103:107-114

48. Eliza K, Khosa R, Gosain AK, Nema AK (2018) Developing a management plan for Loktak Lake considering Keibul Lamjao National Park and hydropower demand using a data driven modeling approach. Curr Sci 115(9):1793-1798

49. Singh T, Shyamananda RK (1994) Ramsar sites of India: Loktak Lake. World Wide Fund for Nature, New Delhi

50. Singh CR, Thompson JR, French JR, Kingston DG, Mackay AW (2010) Modelling the impact of prescribed global warming on runoff from headwater catchments of the Irrawaddy River and their implications for the water level regime of Loktak Lake, northeast India. Hydrol Earth Syst Sci 14(9):1745-1765
51. NBSS and LUP (2001) Land capability classes of catchment area of Loktak Lake, Manipur. National Bureau of Soil Survey and Land Use Planning, Regional Centre, Jorhat and Kolkata

52. G. of M (2013) Directorate of Environment. Manipur State Action Plan on Climate Change

53. FSI (2003) The state of forest report. Forest Survey of India, Ministry of Environment and Forests, Dehradun, India

54. FSI (2015) State Forest Department, Government of Manipur

55. Eliza K, Khosa R, Gosain AK, Nema AK, Mathur S, Yadav B (2018) Modeling simulation of river discharge of Loktak Lake catchment in Northeast India. J Hydrol Eng 23(8):1-13

56. DHI (2009) MIKE 11 water quality (Ecolab) reference manual, vol C

Publisher's Note Springer Nature remains neutral with regard to jurisdictional claims in published maps and institutional affiliations. 